Nig. J. Biotech. Vol. 36 (1): 113-121 (June 2019)

ISSN: 01891731

Available online at

http://www.ajol.info/index.php/njb/index

and www.biotechsocietynigeria.org

DOI: https://dx.doi.org/10.4314/njb.v36i1.15

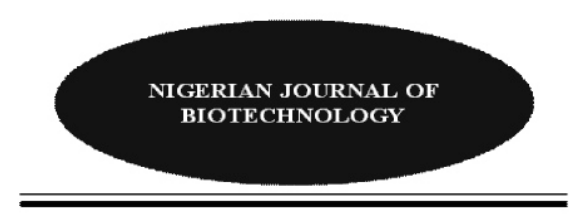

\title{
Immobilization of cellulase and yeast for the hydrolysis and fermentation of pre-treated bagasse for ethanol production
}

Egwim, E. C., Agboola, A. O. and Saidu, A. N.

Biochemistry Department, Federal University of Technology, PMB 65, Minna, Niger State.

Nigeria. Center for Genetic Engineering and Biotechnology, Federal University of Technology, Minna, Niger State, Nigeria.

Copyright resides with the authors in terms of the Creative Commons License 4.0.

(See http://creativecommons.org/licenses/by/4.0/).

Condition of use: The user may copy, distribute, transmit and adapt the work, but must recognize the authors and the Nigerian Journal of Biotechnology.

\section{Abstract}

Lignocellulose ethanol promises to be the cheapest form of fuel, however, the drawback in the production is in the pretreatment process to remove lignin and the efficient hydrolysis of free cellulose. This research work is designed to delignify sugarcane bagasse, hydrolyze and ferment it with immobilized cellulase from the snail gut isolates and yeast respectively. The biomass were pretreated with $\mathrm{Ca}(\mathrm{OH})_{2}$ and then placed in the water-bath with temperature of $20^{\circ} \mathrm{C}, 40^{\circ} \mathrm{C}, 60^{\circ} \mathrm{C}, 80^{\circ} \mathrm{C}, 100^{\circ} \mathrm{C}$ and $120^{\circ} \mathrm{C}$. The pretreated biomass was hydrolysed with free and immobilized cellulase at $50^{\circ} \mathrm{C}$ for $5-48 \mathrm{hrs}$. The activity, optimum pH, optimum temperature, substrate concentration profile and kinetic parameters, $V_{\max }$ and $K_{m}$ of cellulase were also determined. The optimum pH for free and immobilized cellulase ranged from 4.0-5.5 and optimum temperature was recorded at $45^{\circ} \mathrm{C}$ and $55^{\circ} \mathrm{C}$ for free and immobilized cellulase respectively. The effect of temperature on both free and immobilized cellulases showed that immobilized cellulase has higher resistance to temperature than the free cellulase. Also the yield of glucose $(40 \mathrm{mg} / \mathrm{ml})$ was higher with immobilized enzyme after $24 \mathrm{hrs}$. The results obtained has also shown that immobilized cellulase has a higher $\mathrm{Km}$ when compared with free cellulase The maximum reaction rate $\left(V_{\max }\right)$ obtained from Michaelis Menten plots was lower for immobilized cellulase than for the free enzyme. Higher value of $\mathbf{V}_{\max }$ for free enzyme indicated that the enzyme converted more substrate to product per unit time upon saturation with substrate. The biomass was fermented for $48 \mathrm{hrs}$ with immobilized Saccharomyces cerevisiae and the results showed the ethanol yield of $31.75 \%$ at $24 \mathrm{hrs}$ and $70.84 \%$ at $48 \mathrm{hrs}$. The initial glucose concentration was $40 \mathrm{mg} / \mathrm{ml}$ and this significantly reduced to $6.21 \mathrm{mg} / \mathrm{ml}$ after $24 \mathrm{hrs}$ and $1.25 \mathrm{mg} / \mathrm{ml}$ after $48 \mathrm{hrs}$ of the fermentation process. These results showed a proportional increase in ethanol yield against a depleting concentration of glucose which is being used up in the fermentation reaction revealing the maximum efficiency of the immobilized yeast cells. In this study, it has shown that the entrapped cellulase cells produced high levels of reducing sugars in hydrolysis compared with their native counterparts and immobilized yeast cells also gave a high yield of ethanol. The immobilization process therefore obtained more thermostable biocatalysts with increased productivity which is more economical for biofuel production.

Key words: Immobilization, Cellulase, Saccharomyces cerevisiae, biocatalysts, delignification

Corresponding author:c.egwim@futminna.edu.ng+2347065809474 


\section{Introduction}

Bioethanol is becoming one of the main actors in the fuel market. The depletion of fossil fuel reserves and the unstable petrol price have led to intensive search for renewable energy sources such as solar energy, geothermal energy and also energy from biomass. One of the commonest sources of bioethanol production are materials such as sugar cane, corn and wheat which have high sugar and starch contents. Ethanol made from sugar cane biomass (bagasse \& straw) as well as other lignocelluloses materials has one unprecedented feature as it could generate viable and sustainable energy sources, which are ecofriendly, safe and very clean. It may be a potential replacement to fossil fuels, therefore, lignocellulose biomass can act as a cheap substrate with constant supply as a substrate for bioconversion to fuel ethanol Cellulose, hemicellulose and lignin are the key biomass polymers found in sugarcane bagasse consisting about 50, 27.5 and $9.8 \%$ respectively (Girio et al., 2010). The rest $11.3 \%$ are cell contents of sugarcane. Natural cellulose is a crystalline and linear polymer of thousands of $D$ glucose residues linked by $\beta-1,4-$ glycosidic bonds, considered the most abundant and renewable biomass resource and a formidable reserve of raw material (Quiroz-Castañeda and FolchMallol,2013).Structural features of cellulose such as the degree of crystallinity, the degree of polymerization, the degree of water swelling, and the surface area, limit accessibility of substrate to enzyme and have been demonstrated to affect the rate of enzymatic hydrolysis of cellulose. Pretreating lignocellulosic biomass to disrupt the lignin-carbohydrate complex, to decrease native cellulose crystallinity (cellulose I), and to partially remove lignin and hemicellulose, has been shown to significantly enhance the subsequent hydrolysis of cellulose (Kumar et al., 2009). Immobilization allows one to re-use the enzyme for an extended period of time and enables easier separation of the catalyst from the product. Additionally, immobilization improves many properties of enzymes such as performance in organic solvents, $\mathrm{pH}$ tolerance, heat stability or the functional stability. Increasing the structural rigidity of the protein and stabilization of multimeric enzymes which prevents dissociationrelated inactivation (Guzik et al., 2014). In this study cellulase enzyme from snail gut isolates and Saccharomyce cerevisea were immobilized on chitosan beads for the hydrolysis and production of ethanol from microwave-alkaline pretreated bagasse.

\section{Materials and Methods}

Drying and Pretreatment of Samples: The sugarcane bagasse was purchased from National Cereal Research Institute Bida, Niger State Minna. It was dried and milled to a size less than $1 \mathrm{~mm}$. The milled samples were stored at room temperature. The biomass were pretreated with $\mathrm{Ca}(\mathrm{OH})_{2}$ and then placed in the water-bath with temperature range of $20^{\circ} \mathrm{C}, 40^{\circ} \mathrm{C}, 60^{\circ} \mathrm{C}, 80^{\circ} \mathrm{C}$, $100^{\circ} \mathrm{C}$ and $120^{\circ} \mathrm{C}$. Giant snail (Achatina Maginata), from which cellulase was isolated, was bought from Kure Central Market Minna.

\section{Microorganisms}

Aspergillus niger isolated from snail gut was used for the production of cellulase enzyme. The microorganism was placed in a basal medium just like the modified medium of Deacon (1985) containing (in gram per liter), $2.0 \mathrm{~g} / \mathrm{L}$ yeast extract, $5.0 \mathrm{~g} / \mathrm{L} \mathrm{NaNO}{ }_{3} 1.0 \mathrm{~g} / \mathrm{L} \mathrm{KH}_{3} \mathrm{PO}_{4}, 0.5 \mathrm{~g} / \mathrm{L}$ $\mathrm{MgSO}_{3} .7 \mathrm{H}_{2} \mathrm{O}$, and $0.001 \mathrm{~g} / \mathrm{L} \mathrm{FeCl}_{3}$. To the culture mixture, an addition of $1 \%$ Carboxyl methyl cellulose was made. The culture mixture was then allowed to grow for a week (seven days) at room temperature. By filtering the culture mixture with Whatman no 1 filter paper, the filtrate was then used as the enzyme solution (Singh et al., 1988).

Immobilization of cellulase and assay: The immobilization procedure was carried out according to the method of Andriani et al., (2012) with slight modifications. The chitosan beads were added to cellulase solution with a given enzyme/beads ratio ( $2 \mathrm{ml} / \mathrm{g}$ beads) and the solution stirred with magnetic stirrer at $25^{\circ} \mathrm{C}, 150$ rpm for 2 hours and then placed in refrigerator for 24 hours at $4^{\circ} \mathrm{C}$. The supernatant was removed and the chitosan beads with adsorbed enzyme were separated and washed thrice with $100 \mathrm{mM}$ Phosphate Citrate buffer (pH 7.0) to remove the unbound enzyme.

Assay reaction for the immobilized cellulase was set up using DNSA method according to the protocols described Shoemaker and Brown 1998. For assay, $100 \mathrm{mg}$ immobilized cellulase was added into $3 \mathrm{ml}$ of $1 \%$ Carboxyl methyl cellulose (CMC) dissolved in a citrate buffer ( $\mathrm{pH}$ 4.0). The mixture was incubated at $40^{\circ} \mathrm{C}$ for 20 mins and filtered. The reaction was terminated by adding $3 \mathrm{ml}$ of 3,5-dinitrosalicylic acid (DNSA) reagent, heated at a temperature $100^{\circ} \mathrm{C}$ for 15 minutes and cooled to room temperature. The activities of the immobilized enzyme were determined using spectrophotometer and the absorbance was read at 540nm The enzyme activity was measured in 
mmol glucose that was released in $1 \mathrm{~min}$ per $1 \mathrm{ml}$ of the filtrate. The immobilized enzyme was characterized for optimum temperature, optimum $\mathrm{pH}$ and the enzyme loading time.

\section{Optimum Temperature and $\mathrm{pH}$ :}

The effect of temperature was studied by incubating the free cellulase enzyme and the immobilized enzyme ( $\mathrm{Im}$ ) each in $3 \mathrm{ml}$ of $1 \% \mathrm{CMC}$ (dissolved in $0.05 \mathrm{M}$ citrate phosphate buffer $\mathrm{pH}$ 4.0). The mixtures were placed in a water bath at different temperature $30^{\circ} \mathrm{C}, 40^{\circ} \mathrm{C}, 50^{\circ} \mathrm{C}, 60^{\circ} \mathrm{C}$ and $70^{\circ} \mathrm{C}$ for $20 \mathrm{mins}$ by the method of Akinsoye et al. (1995) and by following assay conditions according Dey et al. (2003) with minor modifications. The activities were measured as above.

The optimum $\mathrm{pH}$ for free enzyme was determined by incubating $1 \mathrm{ml}$ in $3 \mathrm{ml} \% \mathrm{CMC}$ at different $\mathrm{pH}$ values of the buffer ranging from 3 7. The solutions were incubated at $50^{\circ} \mathrm{C}$ for 20 mins and the activities determined as above.

Kinectics of the immobilized as well as free enzyme was analyzed using Lineweaver-Burke and Michaelis- Menten plots. The enzyme kinetics experiment was performed by measuring the initial enzyme reaction velocity at different substrate concentration of starch in $0.05 \mathrm{M}$ citrate buffer. The Lineweaver-Burke plot was used to establish the Michaelis constant $\left(\mathrm{K}_{\mathrm{m}}\right)$ and maximum velocity $\left(\mathrm{V}_{\max }\right)$ of the enzyme reaction.

\section{Hydrolysis of Pretreated Bagasse Using Free and immobilized Cellulase}

Hydrolysis was carried out by the free and immobilized enzyme separately in a $250 \mathrm{~mL}$ shake flask. Cellulase loading of $25 \mathrm{ml} / \mathrm{g}$ pretreated bagasse was mixed and incubated at $50^{\circ} \mathrm{C}$ at $\mathrm{pH} 4.7$ in $0.05 \mathrm{M}$ Sodium citrate buffer. Samples were taken at 4 hours interval for 36 hour to determine the reducing sugar content of the hydrolysis mixture using DNSA method. The absorbance was read at $540 \mathrm{~nm}$.

\section{Fermentation Process to Produce Ethanol from the Pre-treated Bagasse}

Separate Hydrolysis and Fermentation (SHF) was adopted. The hydrolysate of the pre- treated bagasse $(500 \mathrm{ml})$ obtained after $24 \mathrm{hrs}$ enzymatic hydrolysis was filtered and the supernatant was used as a sole carbon source in the fermentation medium. Immobilized yeast nutrients were added to have a basal medium composition of $5.0 \mathrm{~g} / \mathrm{L}$ yeast, extract $5.0 \mathrm{~g} / \mathrm{L}$ peptone, $5.0 \mathrm{~g} / \mathrm{L} \mathrm{NH}_{4} \mathrm{PO}_{4}, 0.2 \mathrm{~g} / \mathrm{L} \mathrm{MgSO}{ }_{4}$ and $7 \mathrm{H}_{2} \mathrm{O}$. Suspension $(2 \% \mathrm{~V} / \mathrm{V})$ of $\mathrm{S}$. Cerevisiae $(10$ cells/ $\mathrm{ml}$ ) was then inoculated to the broth to initiate the fermentation process and incubated at 30 for $48 \mathrm{hrs}$.

\section{Results and Discussion}

Pretreatment of bagasse: The results of the pretreatment of bagasse using alkaline method at different calcium hydroxide concentration and temperature presented in figure 4.1 showed that maximum lignin removal was obtained at $2 \%$ calcium hydroxide treatment at all the temperature of study. Highest lignin removal was recorded at $120^{\circ} \mathrm{C}$ Temperature. It was found out that degree of temperature was inversely proportional to time in lignin removal. The efficiency of lignin removed by this alkaline pretreatment method was examined by estimating the amount of lignin present in the solution after pretreatment. Highest percent $(96 \%)$ of lignin was removed from the sugar cane bagasse when treated with $2 \% \mathrm{Ca}(\mathrm{OH})_{2}$ at $120^{\circ} \mathrm{C}$ given a total yield of $40 \mathrm{mg} / \mathrm{ml}$ of reducing sugar. This result is in agreement with that obtained by Sharma et al. (2012) who demonstrated that the mild reaction of $\mathrm{Ca}(\mathrm{OH})_{2}$ at low concentration prevent condensation of lignin leading to its high solubility and greater removal. Also, in the study carried out by Egwim et al. (2015), it was discovered that the highest biomass reduction (lignin removal) was observed with $8 \% \mathrm{NaOH}$ at $80^{\circ} \mathrm{C}$.As the pretreatment temperature is lowered, time required for efficient lignin removal also increased. The results showed that biomass pretreatment using alkaline assisted with moderate heat and humidity has great and beneficial future prospects. The cost of the alkali has been the hurdle in alkaline pretreatment; however, considering the efficiency, it is cost effective (Verma et al. 2011; Feng and Chen, 2008).

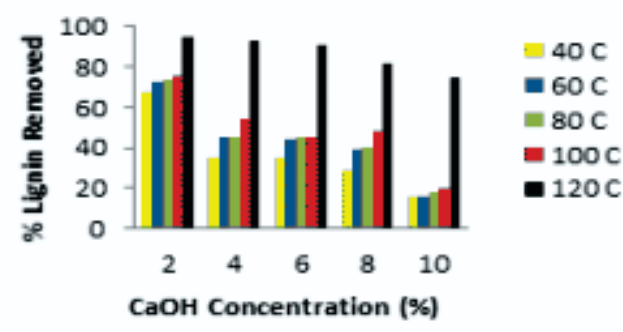

Figure 4.1 Pretreatment of bagasse using alkaline method 
Optimum $\mathrm{pH}$ of Free and Immobilized Cellulase Enzyme: The result of relative activities of free and immobilized enzymes at different $\mathrm{pH}$ is presented in figure 4.2. The result showed that, the optimum $\mathrm{pH}$ for free cellulase is 4.5 and immobilized cellulase is 5.5 . This result is in agreement with that obtained by Viet et al. (2013). They demonstrated that the optimum $\mathrm{pH}$ for free cellulase is 4.5 while the immobilized cellulase $\mathrm{pH}$ range from 5.0 to 7 . Sheila et al. (2014) also demonstrated that for commercial cellulase immobilized on chitosan, both for free and immobilized cellulase proved stable at acidic
$\mathrm{pH}$ medium. He reported that immobilized cellulase retained 50 to $60 \%$ of its initial activity. These differences in the behaviors of free and immobilized enzyme processes could be explained by the poly-cationic nature of the chitosan used for enzyme support. They attract more $\mathrm{OH}$ - ions around the immobilized enzyme, thus making the $\mathrm{pH}$ of the enzyme's microenvironment more than the bulk solution which eventually leads to a shift in $\mathrm{pH}$ towards alkalinity. Immobilized enzyme therefore requires a higher $\mathrm{pH}$ for optimal activity than free enzyme (Feng et al., 2009).

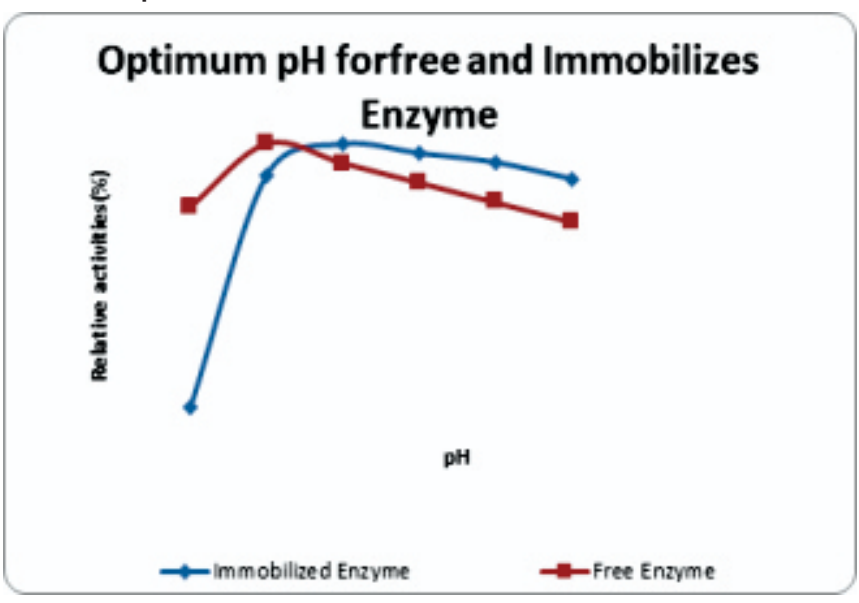

Figure 4.2 Optimum pH for free and immobilized cellulase enzyme from snail gut isolates

Optimum Temperature for Free and Immobilized Cellulase

The optimum temperature for free and immobilized cellulase is shown in figure 4.3. In this study, the optimum temperatures for free and immobilized cellulase were $45^{\circ} \mathrm{C}$ and $55^{\circ} \mathrm{C}$ respectively. This result however agrees with that observed by Viet et al. (2013). They reported that the activity of free enzyme decrease over a wider range of temperature when compared with the immobilized enzyme which has its optimum temperature at $55^{\circ} \mathrm{C}$. Similar findings are reported by Sheila et al. (2014) that for immobilized cellulase on chitosan beads, enhanced thermal stability was observed with results significantly better than those of the native enzyme at temperatures over $75^{\circ} \mathrm{C}$

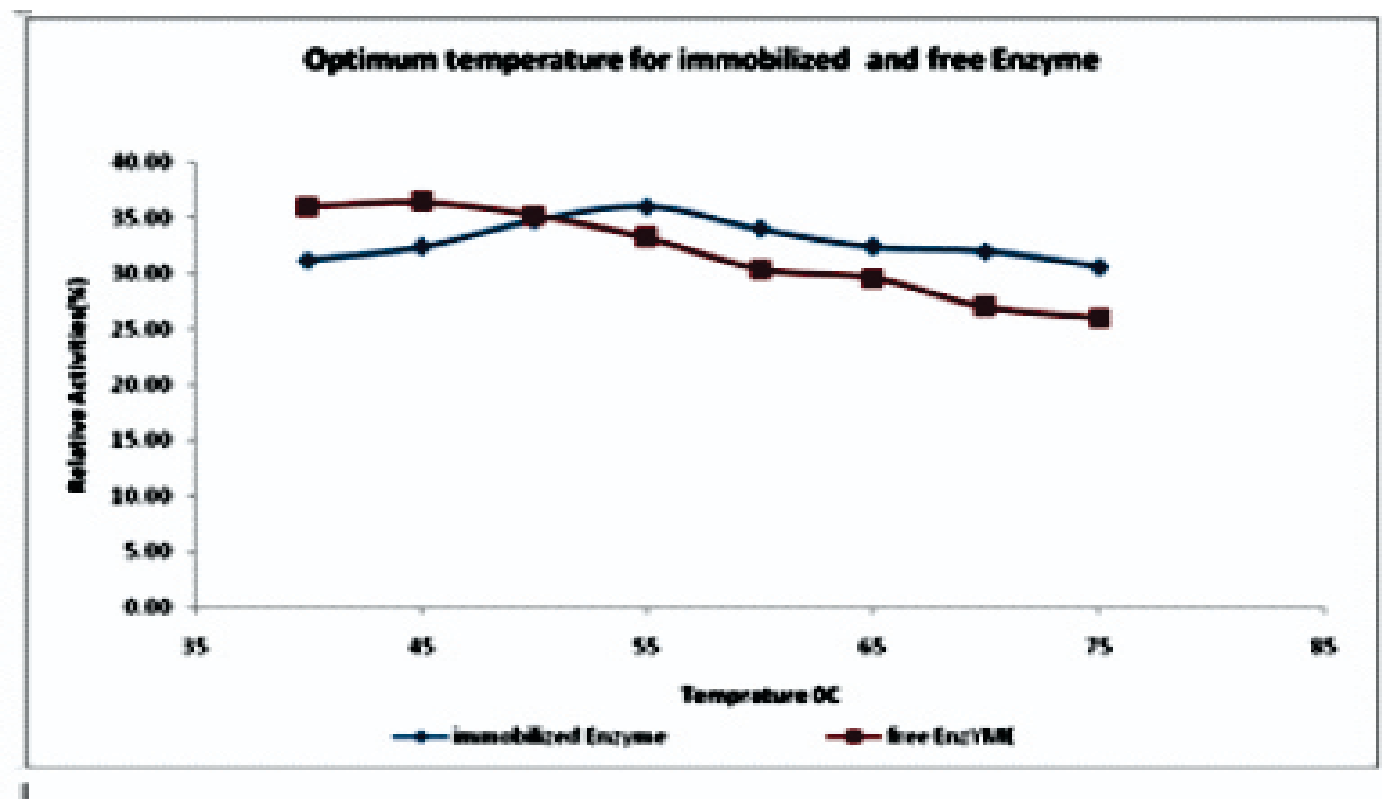

Figure 4.3 Optimum temperature for immobilized and free enzyme from snail gut isolates. 
Cellulase Loading Efficiency on Chitosan Beads: The loading efficiency of enzyme on Chitosan support as shown in figure 4.4 indicated the highest efficiency was at a loading of $2 \mathrm{ml}$ of enzyme/g of support. Increased loadings beyond $2 \mathrm{ml}$ of enzyme/g of support led to progressive decrease in efficiency of the enzyme. This result is in accordance with those obtained in the study conducted by Pereira et al., (2003). They found out that the hydrolytic activity of immobilized enzyme increased as more enzyme was loaded onto the support until it reaches a particular threshold where reduction in activity was observed. The results suggested that instead of obtaining the desired crowded upright adsorption of enzyme onto the support surface multilayer adsorption occurred, possibly blocking access to enzyme active sites. Some previous experimental works that have been done were carried out using immobilized preparation at cellulase loadings of $2 \mathrm{ml}$ enzyme $\mathrm{g}^{-1}$ of dry chitosan beads.

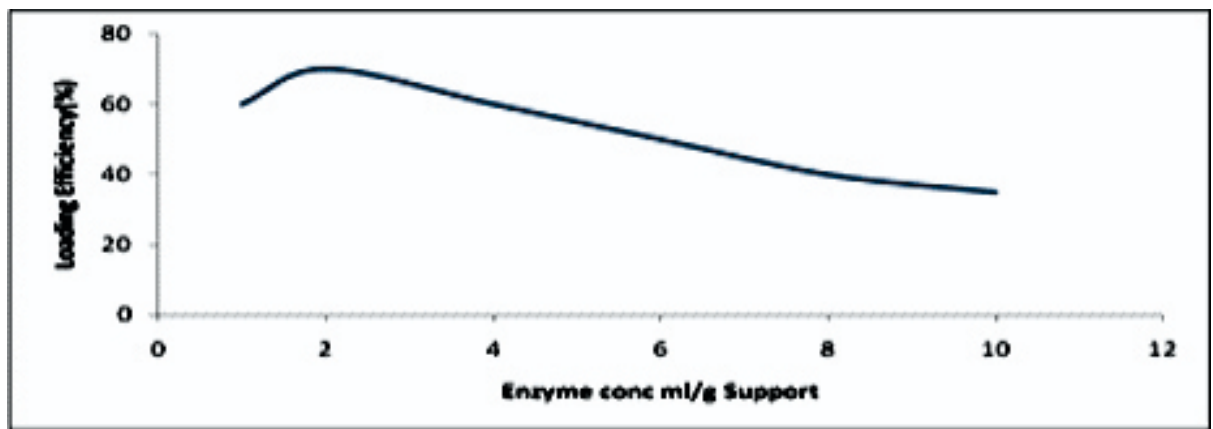

Fig. 4.4 Effect of cellulase loading on loading efficiency

Substrate Effect and Enzyme Kinetics $\left(V_{\max }\right.$ and $\left.K_{m}\right)$ : Kinectics of immobilized cellulase was determined at $\mathrm{pH}$ and temperature of 5.5 and $55^{\circ} \mathrm{C}$ while for free enzyme at 4.0 and $45^{\circ} \mathrm{C}$ respectively. The kinetic constant $\left(\mathrm{K}_{\mathrm{m}}\right)$ and the maximum reaction rate $\left(\mathrm{V}_{\max }\right)$ were obtained from Lineweaverburk plots as shown in figure 4.5. With regard to these parameters, immobilization prompted an increase in the value of $\mathrm{K}_{\mathrm{m}}$, which might be due to changes in the accessibility of the substrate to the active sites of the enzyme caused by diffusional limitations, steric effects and enzyme structural changes following immobilization (Monier et al.,2010). The results of this study showed a decrease in $\mathrm{K}_{\mathrm{m}}$ for free cellulose which indicates faster reaction rate, whereas an increase of the $\mathrm{K}_{\mathrm{m}}$ suggest the requirement of higher substrate concentration to achieve same reaction rate observed for the free enzyme Luz et al., (2014). These findings agree with that obtained by El-Masry et al. (2001). They stated that the immobilized enzyme decreased its affinity for substrate $\mathrm{K}_{\mathrm{m}}=8.1$ and $1.84 \mathrm{mg} / \mathrm{L}$ for the immobilized enzyme and free enzyme respectively). This result was also in accordance with that reported by Romo-Sánchez et al. (2014). Maximum velocity, $\mathrm{V}_{\max }$ which refers to the substrate decomposition rate ( $\mu \mathrm{mol} \cdot \mathrm{min}-1 \cdot \mathrm{mg}-1)$ unlike $\mathrm{K}_{\mathrm{m}}$ values was smaller for immobilized cellulase and this was also reported by Kumar et al. (2011) and RomoSánchez et al. (2014). Higher value of $V_{\max }$ for free enzyme indicated that the enzyme converted more substrate to product per unit time upon saturation Kumal et al. (2012).

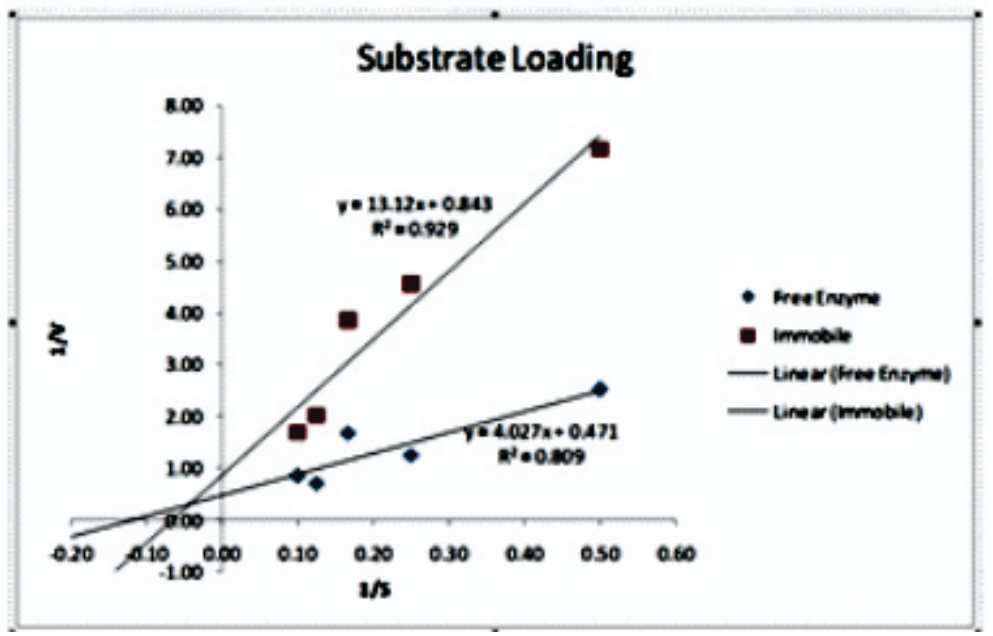

Fig 4.5 Lineweaver Burke plot to determine apparent $\mathrm{K}_{\mathrm{m}}$ for immobilized and free enzyme 
Hydrolysis of Bagasse Using Immobilized and Free Cellulase Enzyme: The result obtained showed that increase in cellulase loading time resulted in increase in the yield of glucose $(\mathrm{mg} / \mathrm{ml})$ in both immobilized and free enzymes (figure 4.6). After hydrolysis with immobilized cellulase, the reducing sugars yield reached more than 27 $\mathrm{mg} / \mathrm{ml}$ in $20 \mathrm{hrs}$ and up to $40 \mathrm{mg} / \mathrm{ml}$ within $24 \mathrm{hrs}$ while only about $7 \mathrm{mg} / \mathrm{ml}$ of glucose yield was obtained after $24 \mathrm{hrs}$ for its free counterpart. Increase in enzyme loading time beyond these hours for both immobilized and free cellulase enzymes had no further effect on percent glucose yield. The above result indicated that the available space on the immobilization carrier became saturated with prolonged loading time; hence the immobilized enzymes attained highest activity within 24 hrs of hydrolysis process.

These results showed that the hydrolysis of bagasse was highly effective within $24 \mathrm{hrs}$ with immobilized enzyme when compared with the reducing sugar yield with free enzyme within the same hours. It is evident by these results that maximum glucose yield could be obtained within short time with immobilized cellulase which ultimately implies more ethanol yield from the available reducing sugars. This also was reported by Roth et al., (2013) after application of immobilized cellulase and yeast cells for ethanol production.

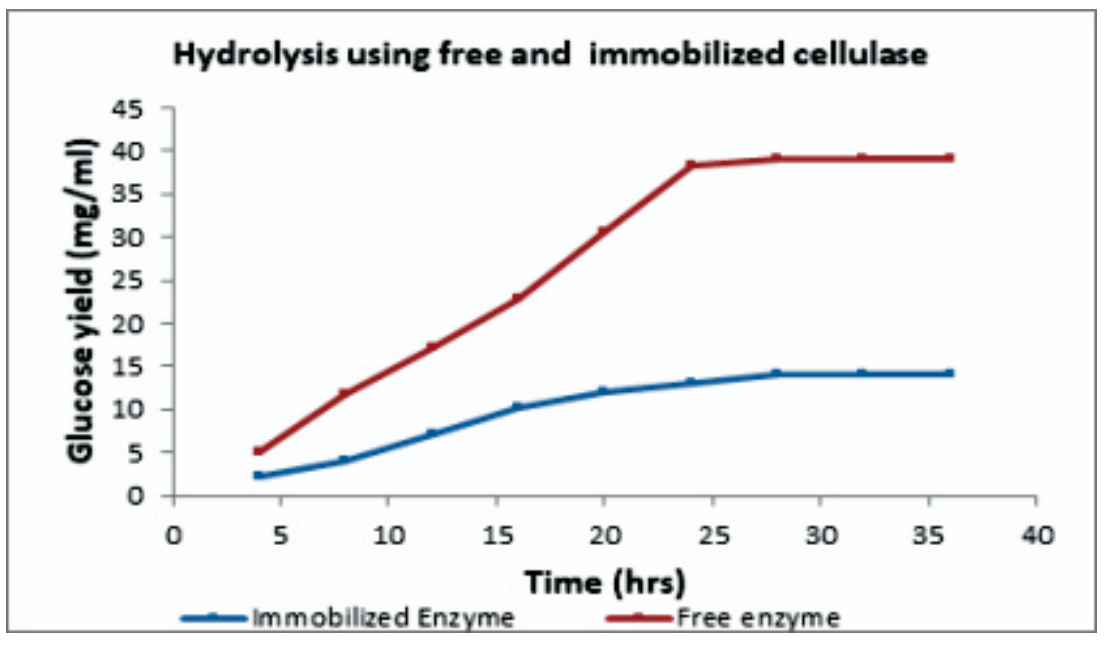

Figure 4.6 Effect of Cellulase Loading Time on Glucose Yield

Analysis of Ethanol Distillate.

Production of ethanol with immobilized Saccharomyce cerevisiae (yeast cell) was performed for $48 \mathrm{hrs}$. At zero hour, the initial reducing sugar concentration was $40 \mathrm{mg} / \mathrm{ml}$ and this significantly decreased to $6.21 \mathrm{mg} / \mathrm{ml}$ and $1.25 \mathrm{mg} / \mathrm{ml}$ after $24 \mathrm{hrs}$ and $48 \mathrm{hrs}$ of the fermentation process respectively as presented in figure 4.7. The ethanol yields reached $31.75 \%$ and $70.84 \%$ respectively at $24 \mathrm{hrs}$ and $48 \mathrm{hrs}$ of fermentation process with immobilized yeast cells as shown in figure 4.8. These results showed a proportional increase in ethanol yield against a depleting concentration of glucose which is been used up in the fermentation reaction (figure 4.9). The results presented at Figure 4.7 suggest that immobilized cells consume almost all available sugar during the first 24 hrs of fermentation. This was also in accordance with Janiszyn et al. (2007) who reported $38 \mathrm{~g} / \mathrm{L}$ ethanol at $24 \mathrm{hrs}$. In another study it was observed by Rabelo et al., (2011) that after producing $83.20 \mathrm{~g} / \mathrm{l}$ and $132.39 \mathrm{~g} / \mathrm{L}$ ethanol concentration from molasses and thick juice using immobilized cells of S. cerevisiae, the immobilized yeast showed an important operational stability without any decrease of its activity. Maurice (2011) reported $61.48 \%$ and $62.77 \%$ ethanol yields at $24 \mathrm{hrs}$ and $48 \mathrm{hrs}$ respectively for fermentation process with free S. cerevisea with same concentration of reducing sugars $(40 \mathrm{mg} / \mathrm{ml})$. From the results of this study, it can be concluded that immobilized cellulase and yeast cells for hydrolysis and fermentation processes could attain maximum activity and ethanol yield within 24 hrs and 48 hrs of the whole process. Low fermentation times indicated that no period was needed for adaptation of biocatalyst in the fermentation environment considering the established alkaline nature of the chitosan carrier. 
Egwim et al./ Nig. J. Biotech. Vol. 36 Num. 1: 113-121 (June 2019)

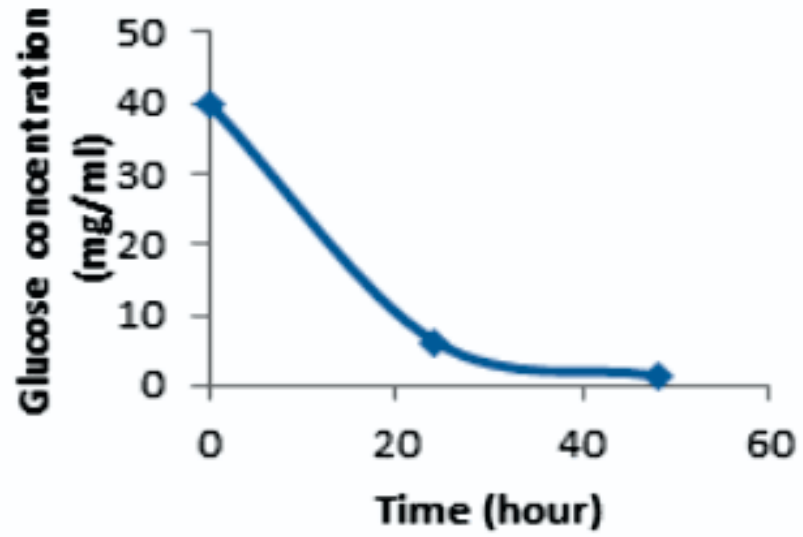

Fig 4.7 Effect of time on glucose concentration in fermentation process

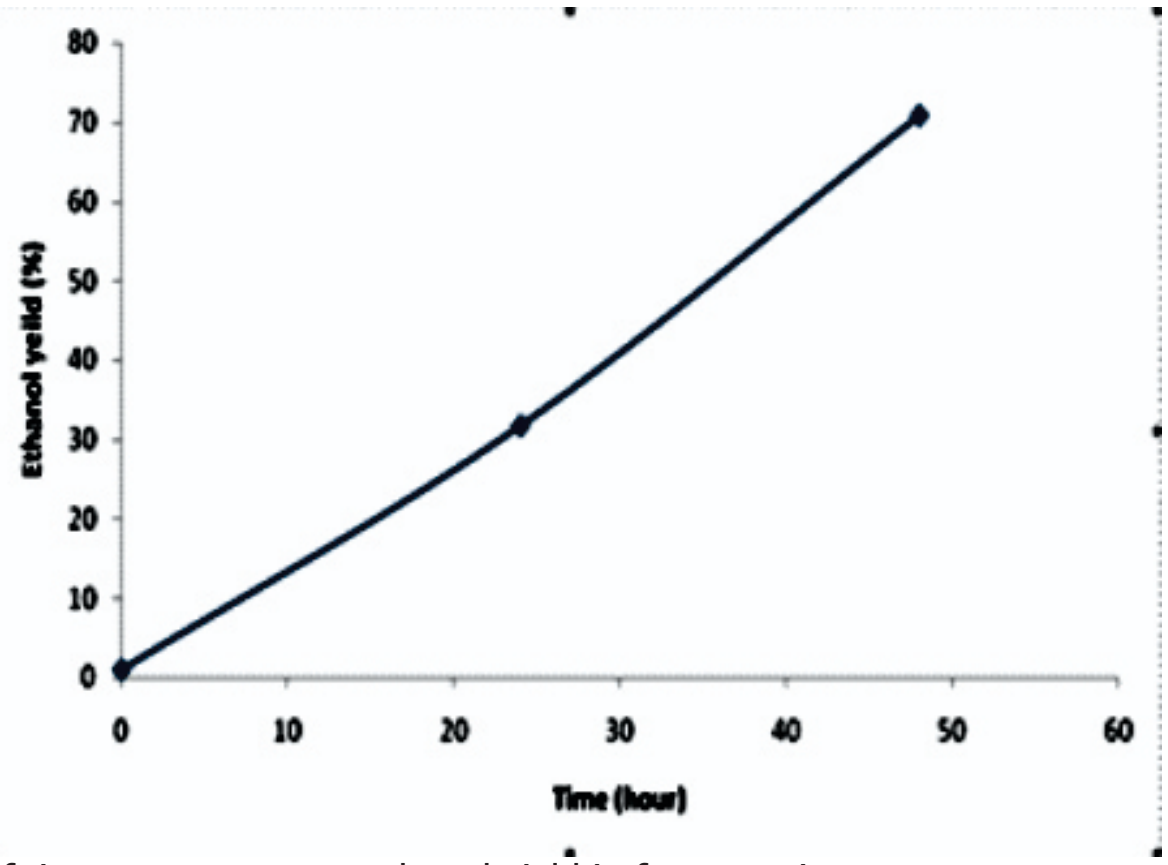

Fig 4.8 Effect of time on percentage ethanol yield in fermentation process

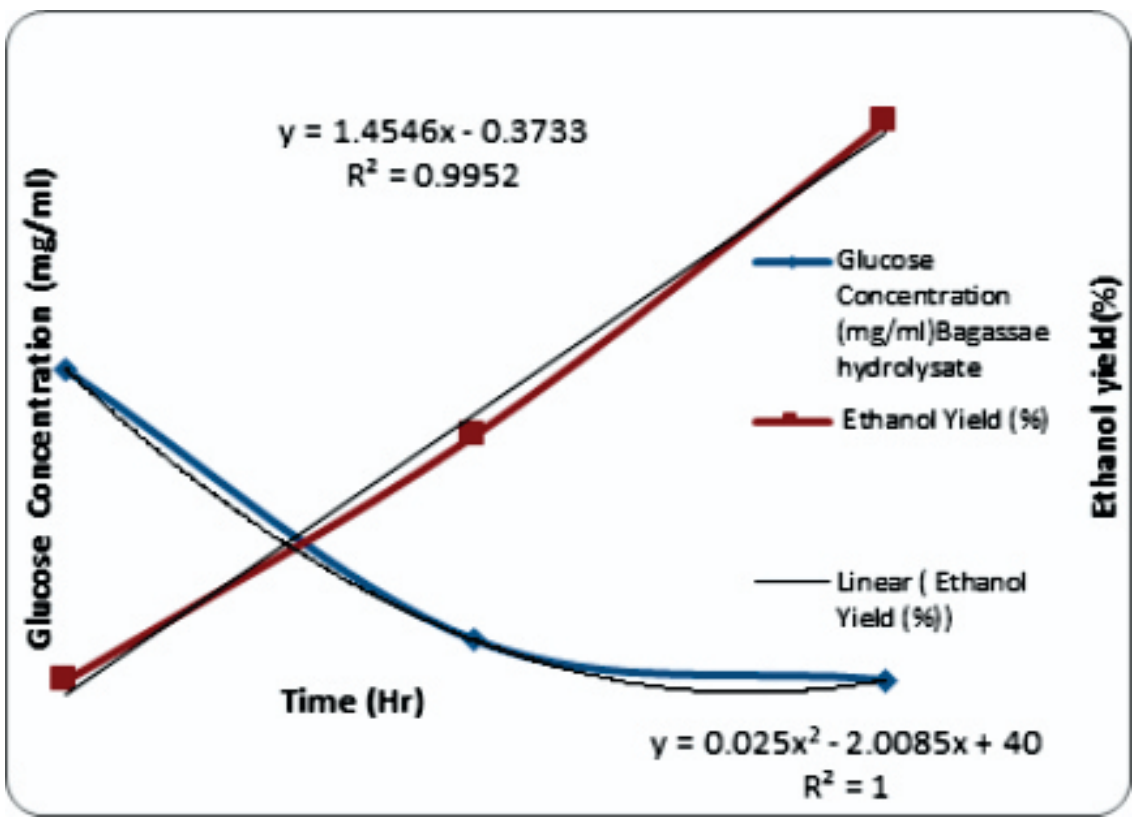

Fig. 4.9 Percentage yield of ethanol from bagasse hydrolysate 


\section{References}

Akinyosoye, F. A, Arotupin, D. J, Akinyanju, J. A (1995) Cellulolytic activity of fresh isolates of Aspergillus niger from sawdust. Biosci. Biotech. Res.Comm. $7(1)$, 25-26.

Andriani, D., Sunwoo, C., Ryu, H. W., Prasetya, B., \& Park, D. H. (2012). Immobilization of cellulase from newly isolated strain Bacillus subtilis TD6 using calcium alginate as a support material. Bioproc Biosys Eng, 35(1-2), 29-33.

Egwim, E. C., Oluwatisin, S. K., \& Deborah, K. (2015). Microwave-alkaline assisted pretreatment of banana trunk for bioethanol production. J. Energy and Power Engineering, 9, 705-13.

Deacon, H. J. (1985). Late Pleistocene human fossils and evolutionary relationships. In ancestors: the hard evidence. Delson Journal, 296-300.

Dey, I. (2003). Qualitative data analysis: A user friendly guide for social scientists. Routledge.

El-Masry, M. M., De Maio, A., Portaccio, M., Di Martino, S., Bencivenga, U., Rossi, S., ... \& Mita, D. G. (2001). Isothermal and non-isothermal characterization of catalytic nylon membranes chemically grafted: dependence on the grafting percentage. Enzyme microb.Technol. 28(9-10), 773-784.

Feng L, \& Chen Z (2008) Research progress on dissolution and functional modification of cellulose in ionic liquids. J Mol Liq 142:1-5

Girio, F. M., Fonseca, C., Carvalheiro, F., Duarte, L. C., Margues, S., \& Bogel, L. R. (2010). Hemocelluloses for ethanol: a review. Bioresour Technol, 101, 4775-4800.

Guzik, U., Hupert-Kocurek, K., \& Wojcieszyńska, D. (2014). Immobilization as a strategy for improving enzyme properties-application to oxidoreductases. Molecules, 19(7), 8995-9018.

Janiszyn, Z., Dziuba, E., Boruczkowski, T., Chmielewska, J., Kawa-Rygielska, J., \& Rosiek, G. (2007). Application of porous ceramic sinter as a support for immobilization of Saccharomyces cerevisiae yeast cells. Pol J Food and Nutr Sci, $57(4[B])$

Kumar, L., Arantes, V., Chandra, R. \& Saddler, J., (2012). The lignin present in steam pretreated softwood binds enzymes and limits cellulose accessibility. Bioresour. Technol. 103, 201-208.

Kumar, P., Barrett, D. M., Delwiche, M. J., \& Stroeve, P. (2009). Methods for pretreatment of lignocellulosic biomass for efficient hydrolysis and biofuel production. Ind Eng Chem Res, 48(8), 3713-3729.

Luz, R. A., Pereira, A. R., de Souza, J. C., Sales, F. C., \& Crespilho, F. N. (2014). Enzyme biofuel cells: thermodynamics, kinetics and challenges in applicability. Chem. Electro. Chem, 1(11), 1751-1777.

Maurice, M. L. (2011). Factors effecting ethanol fermentation via simultaneous saccharification and fermentation. Project submitted to the faculty of Worcester Polytechnic Institute in partial fulfillment of the requirements for the Degree of Bachelor Science. Pg1-42

Monier, M., Ayad, D. M., Wei, Y., \& Sarhan, A. A. (2010). Immobilization of horseradish peroxidase on modified chitosan beads. Int. ] Biol Macromol, 46(3), 324-330.

Pereira, E. B., Zanin, G. M., \& Castro, H. F. (2003). Immobilization and catalytic properties of lipase on chitosan for hydrolysis and esterification reactions. $\mathrm{Br}$ ] Chem Eng, 20(4), 343-355.

Quiroz-Castañeda, R. E., \& Folch-Mallol, J. L. (2013). Hydrolysis of biomass mediated by cellulases for the production of sugars. In Sustainable degradation of lignocellulosic biomass-techniques, applications and commercialization. IntechOpen.

Rabelo, S. C., Fonseca, N. A., Andrade, R. R., Maciel Filho, R., \& Costa, A. C. (2011). Ethanol production from enzymatic hydrolysis of sugarcane bagasse pretreated with lime and alkaline hydrogen peroxide. Biomass and bioenergy, 35(7), 2600-2607.

Romo-Sánchez, S., Camacho, C., Ramirez, H. L., \& Arévalo-Villena, M. (2014). Immobilization of commercial cellulase and xylanase by different methods using two polymeric supports. Adv Biosci Biotechnol, 5(06), 517.

Roth, T., Kreis, P., \& Górak, A. (2013). Process analysis and optimisation of hybrid processes for the dehydration of ethanol. Chem Eng Res Des 91(7), 1171-1185.

Sharma, M., Khan, A. A., Puri, S. K., \& Tuli, D. K. (2012). Wood ash as a potential heterogeneous 
catalyst for biodiesel synthesis. Biomass \& bioenerg., 41, 94-106.

Sheila, R.S., Conrado C., Hector, L. R., \& Maria, A. V. (2014). Immobilization of commercial cellulose and xylanase by different methods using two polymeric support. Adv Biosci Biotchnol, 5, 517526.

Shoemaker, H. E., \& Brown J. R.(1998). Buffer methods for determination of lime requirements of soils with appreciable amounts of exchangeable aluminum., Soil Sci Soc Am J , 25:274-277.
Singh, N. P., McCoy, M. T., Tice, R. R., \& Schneider, E. L. (1988). A simple technique for quantitation of low levels of DNA damage in individual cells. Exp Cell Res 175, 184-191.

Verma, N., Bansal, M. C., \& Kumar, V. (2011). Pea peel waste: a lignocellulosic waste and its utility in cellulase production by Trichoderma reesei under solid state cultivation. Bioresources, 6(2), 1505-1519.

Viet, T. Q., Minh, N. P., \& Dao, D. T. A. (2013). Immobilization of cellulase enzyme in calcium alginate gel and its immobilized stability. Am J of Res Commun, 1(12), 254-267. 